УДК 657.1

\title{
ОРГАНИЗАЦИЯ БУХГАЛТЕРСКОГО УЧЕТА РАСЧЕТНЫХ ВЗАИМООТНОШЕНИЙ С ПОСТАВЩИКАМИ И ПОДРЯДЧИКАМИ НА ПРЕДПРИЯТИИ
}

\section{Самылина Юлия Николаевна}

к.э.н., доцент

Ключенова Наталья Дмитриевна

АНО ВО Московский гуманитарно-экономический университет

(Тверской филиал)

Аннотация: Статья посвящена рассмотрению расчетов с поставщиками и подрядчиками как объекта бухгалтерского учета. В связи с этим возникает необходимость грамотного построения учетной процедуры расчетных взаимоотношений с поставщиками и подрядчиками. От объективности и достоверности информации, формируемой на этом участке учета, зависят действия других служб организации.

Ключевые слова: бухгалтерский учет, поставщики, подрядчики, расчеты.

\section{ORGANIZATION OF ACCOUNTING AND SETTLEMENT RELATIONSHIPS WITH SUPPLIERS AND CONTRACTORS IN THE ENTERPRISE}

\section{Yulia N. Samylina Klucinova Natalia}

\begin{abstract}
Article is devoted to the consideration of payments with suppliers and contractors as an object of accounting. In this regard, there is a need for competent construction of accounting procedures for settlement relationships with suppliers and contractors. The actions of other services of the organization depend on the objectivity and reliability of the information generated in this section of accounting.
\end{abstract}

Key words: accounting, suppliers, contractors, calculations. 
Учет расчетов с поставщиками и подрядчиками является важным элементом в системе бухгалтерского учета практически любой организации. При этом под организациейпроцедуры бухгалтерского учета расчетов с поставщиками и подрядчиками следует понимать систему взаимосвязанных элементов, которая, прежде всего, предполагает разработку документооборота; построение аналитического и синтетического учета, контроль за исполнением текущих обязательств перед поставщиками и подрядчиками. Бухгалтерский учет обязательств перед поставщиками и подрядчиками предполагает решение следующих задач.

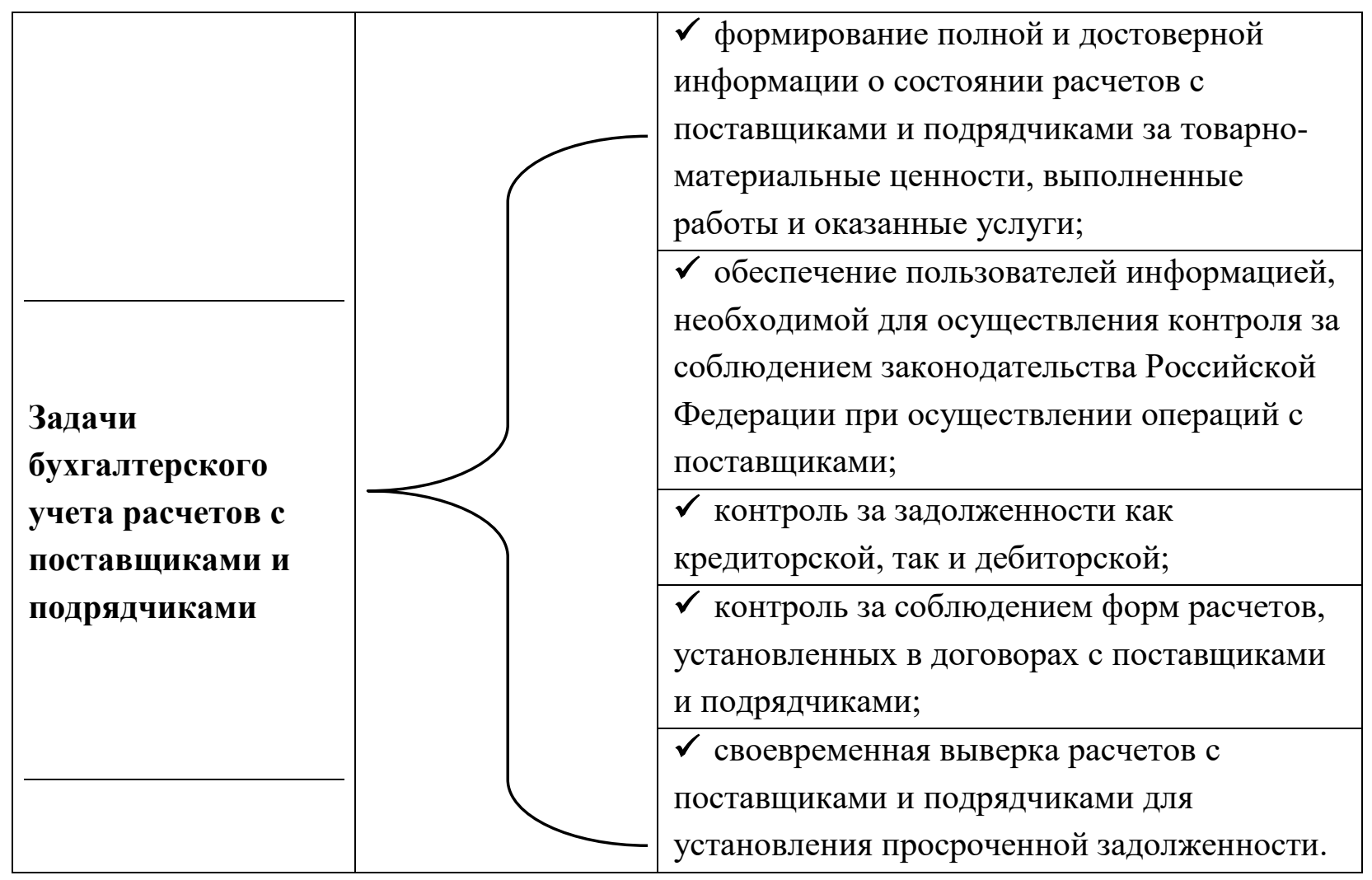

\section{Рис. 1. Задачи учета расчетов с поставщиками и подрядчиками}

Во многом задачи бухгалтерского учета конкретного учетного объекта определяют функциональные обязанности работника бухгалтерской службы, отвечающего за процедуру его учета [4, с. 15]. При этом диапазон выполняемых функции включает учетные работы от оформления первичных документов до подготовки данных для формирования бухгалтерской финансовой и налоговой отчетности. 
Как правило, должностные обязанности бухгалтера, осуществляющего учет расчетов с поставщиками и подрядчиками, представленыдостаточно широким набором функция.

\begin{tabular}{|c|c|}
\hline & $\begin{array}{l}\text { 1. Ведение первичного учета - принятие } \\
\text { уучету надлежаще оформленных } \\
\text { расчетных документов от поставщиков и } \\
\text { подрядчиков }\end{array}$ \\
\hline \multirow{7}{*}{$\begin{array}{c}\text { Должностные } \\
\text { обязанности } \\
\text { бухгалтера по } \\
\text { учету } \\
\text { расчетов с } \\
\text { поставщиками и } \\
\text { подрядчиками }\end{array}$} & $\begin{array}{l}\text { 2. Ведение регистров учета по счету } 60 \\
\text { «Расчеты с поставщиками и } \\
\text { подрядчиками», в том числе в разрезе } \\
\text { субсчетов. }\end{array}$ \\
\hline & $\begin{array}{l}\text { 3. Ведение регистров аналитического } \\
\text { учета по счету } 60 \text { «Расчеты с } \\
\text { поставщиками и подрядчиками» (по } \\
\text { каждому поставщику и подрядчику и по } \\
\text { каждой сделке); }\end{array}$ \\
\hline & $\begin{array}{l}\text { 4. Представление результатов учета } \\
\text { расчетов с поставщиками и подрядчиками } \\
\text { главному бухгалтеру по указанному сроку } \\
\text { (числа каждого месяца) }\end{array}$ \\
\hline & $\begin{array}{l}\text { 5. Обработка выверка счетов-фактур с } \\
\text { книгой покупок по возмещению НДС из } \\
\text { бюджета; }\end{array}$ \\
\hline & $\begin{array}{l}\text { 6. Составление ежеквартальной } \\
\text { расшифровки по задолженности } \\
\text { дебиторов и кредиторов; }\end{array}$ \\
\hline & $\begin{array}{l}\text { 7. Осуществление контроля за } \\
\text { своевременным оприходованием сырья и } \\
\text { материалов на материальный склад в } \\
\text { соответствии с первичными документами. }\end{array}$ \\
\hline & $\begin{array}{l}\text { 8. Осуществление контроля за } \\
\text { сохранностью бухгалтерских документов, } \\
\text { оформление их в соответствии с } \\
\text { установленным порядком. }\end{array}$ \\
\hline
\end{tabular}

\section{Рис. 2. Должностные обязанности бухгалтера по учету расчетов с поставщиками и подрядчиками}

Технологическая схема обработки информации по учету расчетов с поставщиками и подрядчиками. 


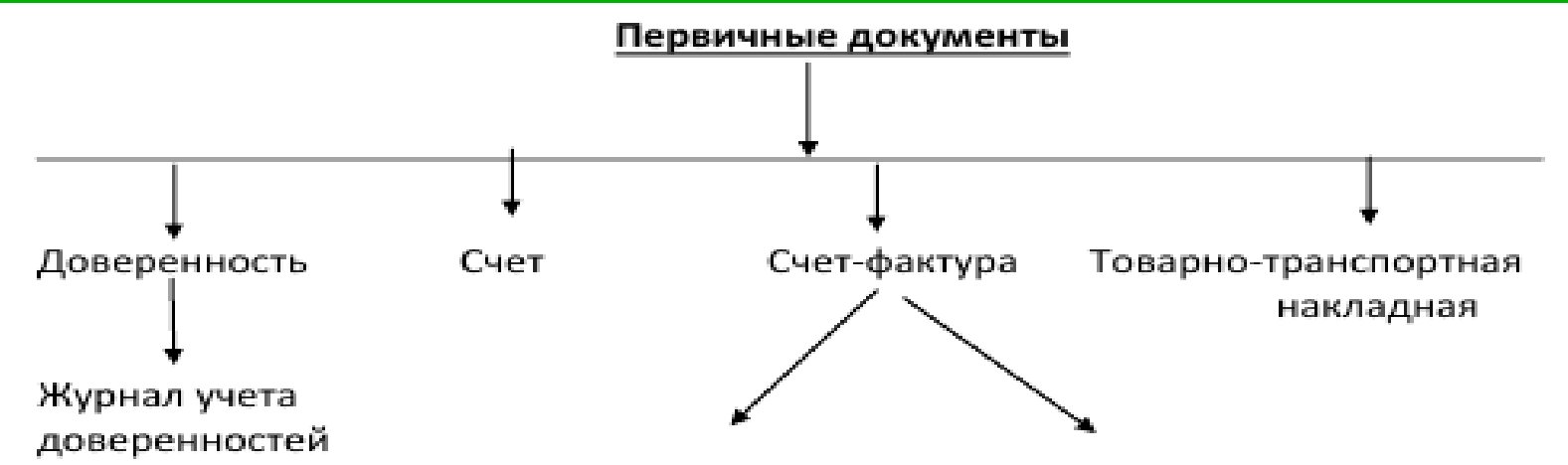

Журнал регистрации

Реестр операций по расчетам полученных счетов-фактур

с поставщиками и подрядчиками

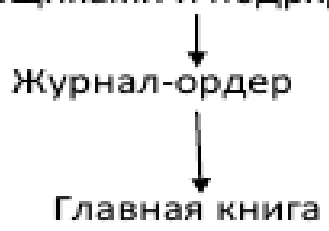

\section{Рис. 3. Схема бухгалтерского учета расчетов с поставщиками и подрядчиками}

C целью бухгалтерского учета расчетных взаимоотношений с поставщиками и подрядчиками применяется счет 60 «Расчеты с поставщиками и подрядчиками». Нормы законодательства определяют, что счет 60 «Расчеты с поставщиками и подрядчиками» является активнопассивным счетом, что предполагает возможность наличия одновременно и кредитового и дебетового остатков [3].

Кредитовыйостаток означает, что у предприятия есть невыполненные обязательства по текущим расчётам с поставщиками. Дебетовый остаток показывает свои обязательства как раз поставщики и подрядчики в рамках подученных ими авансов и предоплат.

Поступление от поставщиков материальных ценностей, стоимость произведенных подрядчиками работ и оказанных услуг отражается по кредиту счета счет 60 «Расчеты с поставщиками и подрядчиками». Дебет счета отражает суммы оплаченных поставщикам счетов, а так же выплаченных авансов и предоплат.

Практика осуществления расчетных операций предполагает детализацию информации по расчетам с поставщиками и подрядчиками. Уровень и порядок детализации такой информации определяется рабочим планом счетов хозяйствующего субъекта.

В соответствии с рабочим планом счетов для учета расчетов с поставщиками и подрядчиками к счету 60 «Расчеты с поставщиками и подрядчиками», открыты субсчетаи аналитические счета (табл.1). 
Таблица 1

Структура счета 60 «Расчеты с поставщиками и подрядчиками»

\begin{tabular}{|l|l|l|l|l|}
\hline Код & Наименование & Субконто 1 & Субконто 2 & Субконто 3 \\
\hline 60 & $\begin{array}{l}\text { Расчеты с поставщиками и } \\
\text { подрядчиками }\end{array}$ & Контрагенты & Договоры & $\begin{array}{l}\text { Документы } \\
\text { расчетов с } \\
\text { контрагентами }\end{array}$ \\
\hline 60.01 & $\begin{array}{l}\text { Расчеты с поставщиками и } \\
\text { подрядчиками }\end{array}$ & Контрагенты & $\begin{array}{l}\text { Договоры } \\
\text { расчетов с } \\
\text { контрагентами }\end{array}$ \\
\hline $\begin{array}{l}\text { Расчеты по авансам } \\
\text { выданным }\end{array}$ & Контрагенты & Договоры & $\begin{array}{l}\text { Документы } \\
\text { расчетов с } \\
\text { контрагентами }\end{array}$ \\
\hline
\end{tabular}

Отметим, что аналитический учет должен быть организован таким образом, что бы получать данные о состоянии расчетов по каждому поставщику, например: по не оплаченным в срок расчетным документам, по авансам выданным.

Таким образом, организация бухгалтерского учета расчетов с поставщиками и подрядчиками предполагает четкое закрепление должностных обязанностей за соответствующим работником бухгалтерии; регламентирование всех элементов учетной процедуры текущих расчетов и обязательств.

\section{Список литературы}

1. Гражданский кодекс Российской Федерации №151-Ф3: текст с изменениями и дополнениями на 29.12.2019 года. URL: WWW.consultant.ru/ (дата обращения 12.11.2020). Режим доступа: СПС Консультант Плюс. Текст: электронный.

2. Федеральный закон «О бухгалтерском учете» от 06.12.2011 № 402Ф3: текст с изменениями и дополнениями на 01.01.2019 года. URL: WWW.consultant.ru / (дата обращения 12.11.2020). Режим доступа: СПС Консультант Плюс. - Текст: электронный.

3. План счетов бухгалтерского учета финансово-хозяйственной деятельности и Инструкция по его применению. Приказ Минфина РФ от 31.10.2000 №94-Н: текст с изменениями и дополнениями на 18.11.2018 года. URL: WWW.consultant.ru/ (дата обращения 12.11.2020). Режим доступа: СПС Консультант Плюс. - Текст: электронный.

4. Самылина Ю.Н. Сущность и значимость бухгалтерской профессии / Актуальные вопросы теории и практики бухгалтерского учета и финансов. Сборник научных трудов. Материалы научно-практической конференции. Под редакцией В.Н. Кузнецова, А.Н. Бородулина. ТГТУ, 2019. С. 14-18. 